\title{
Masif ağaç malzemenin oyuncak yapımında kullanımı
}

\author{
Sait Dündar Sofuoğlu ${ }^{1 *}(\mathbb{D})$, Murat Özalp ${ }^{1}$ (i)
}

\section{$\ddot{O} \mathbf{z}$}

Masif ağaç malzemenin binlerce kullanım alanlarından biri de oyuncak sektörüdür. Üretimde yenilenebilir, doğal ve insan sağlığı açısından zararsız materyallerin kullanımı günümüzde artan bir değer kazanmıştır. Dünyada önemli bir pazar oluşturan ahşap oyuncak üretiminde ülkeler arasında kıyasıya bir rekabet söz konusudur. Türkiye'nin son 5 yılda yaptığ1 oyuncak ithalatının bedelinin 3 milyar doları aştığı bildirilmiştir. Endüstrileşmenin gelişimi ile birlikte oyuncakların çoğunluğu günümüzde plastik malzemelerden üretilmektedir. Ancak plastik malzemenin oyuncak üretiminde kullanılması sağlık açısından tartışılmaktadır. Bu faktörler göz önüne alındığında ebeveynler, çocuklarına oyuncak seçimi yaparken mümkün olduğunca doğal malzeme seçmeye çalışmaktadırlar. Bu kapsamda oyuncak sektöründe geçmişten günümüze sıklıkla kullanılan ahşap malzemenin kullanımı ile ilgili önemli konulara değinilmiştir. Konu ile ilgili literatür incelenmiştir. Bu kapsamda oyuncağın tanımı ve önemi, ahşabın oyuncak yapımında tercih sebepleri, oyuncak yapımında kullanılan başlıca ağaç türleri hakkında bilgi verilmiştir. Daha sonra ahşap oyuncak yapımında kullanılabilecek kalite sembolleri ve üretiminde dikkat edilecek hususlar hakkında bilgi verilmiştir. Son olarak kullanıcılar açısından satın almada dikkat edilecek hususlara değinilmiş ve çalışma sonuç kısmında değerlendirilerek önerilerde bulunulmuştur.

Anahtar kelimeler: Ağaç malzeme, Oyuncak, Kalite

\section{The use of solid wood material in toy production}

\section{Abstract}

One of thousands of usage areas of solid wood material is toy industry. The use of renewable, natural and harmless materials in production, in terms of human health, has gained an increasing value. There is a cutthroat competition among countries in production of wooden toys, which constitute an important market in the world. It was reported that the number of toys import in Turkey exceeded $\$ 3$ billion in last 5 years. Majority of toys are made of plastic materials with development of industrialization today. However, the use of plastic material in toy production has discussed in terms of health. Considering these factors, parents try to choose as much natural material as possible when choosing toys for their children. In this context, important issues related to use of wooden materials that are often used in toy industry from past to present were mentioned. Literature related to the subject was investigated. Within this scope, it was given information about definition and importance of toy, reasons of preference of wood for toy making, main tree species used in toy production. After that, information about quality symbols and issues to be considered in production of wooden toys were given. Finally, issues to be considered in purchasing for users were mentioned and suggestions were made by evaluating the study in result section.

Keywords: Wooden material, Toy, Quality 


\section{Giriş}

Masif ahşap malzeme yıllardan beri oyuncak sanayinde kullanılmaktadır. İlk dönemlerde yoğun olarak kullanılmasına karşın daha sonraları teknolojinin gelişmesi ve yeni malzemelerin üretime dahil edilmesi ile ahşap malzemenin kullanımında azalma meydana gelmiştir. Ancak günümüzde doğal malzemeye olan ilginin tekrardan ön plana çıkması ahşap malzemeye olan ilginin tekrar artmasını sağlamıştır. Bu çalışmada oyuncak üretiminde doğal bir malzeme olarak masif ağaç malzemenin kullanımı ile ilgili literatür araştırması yapılmıştır.

\section{Oyuncağın tanımı ve önemi}

Çocuklar için oyun ve oyuncak kavramları insanlık tarihi kadar eskidir. Oyun ve oyuncak çocukların zihinsel, duygusal ve bedensel gelişimine katkı sağlayarak çocuğun gelişiminde çok önemli bir rol üstlenmektedir (Dalğar ve Kaya, 2017). Oyuncaklar çocukların oyun amacıyla kullandıkları, ahşap, kauçuk, toprak, plastik, bez, metal vb. malzemelerden imal edilmiş oyun araçlarıdır (Omatça, 2006; Tuncer, 2012). Çocuklarımıza aktarmak istediğimiz temel etik ve kültürel değerlerimizi ürettiğimiz oyuncaklarla şekillendirmek mümkündür (PAGEV, 2017).

Tarihsel süreç içinde önceleri taştan, kemikten, tahtadan daha sonra kumaştan ve demirden yapılan oyuncaklar artık günümüzde genellikle ucuz ve işlenmesi daha kolay hammaddelere ilginin artmasıyla birlikte oyuncak yapımında plastik malzeme kullanımı diğer malzemelerin önüne geçmiştir (Dalğar ve Kaya, 2017). Türkiye'de toplam oyuncak ithalatının en az \% 70'ini plastik oyuncaklar oluşturmaktadır. Türkiye'de plastik oyuncak ihracatı toplam oyuncak ihracatının en az \% 90'ını oluşturmaktadır (PAGEV, 2017).

Ahşabın ekolojik bir malzeme oluşu ebeveynlerin ahşabı tercih etmesinin en önemli nedenidir. Ahşap, işlenmesinin kolay oluşu sebebi ile oyuncak yapımında ahşap atlardan, ahşap arabalara kadar yüzyıllarca tercih edilmiştir. Oyuncağın tarihi de pek çok tarihin, medeniyetin kesiştiği Mısır'a kadar dayanmaktadır. Bütün dünyanın tanıdığı birbiri içine geçen ahşap bebekler olan matruşkaların geçmişi 120 yıl öncesine dayanmaktadır (Omatça, 2006). Şekil 1'de günümüzdeki matruşkalar ve üretimi verilmektedir.

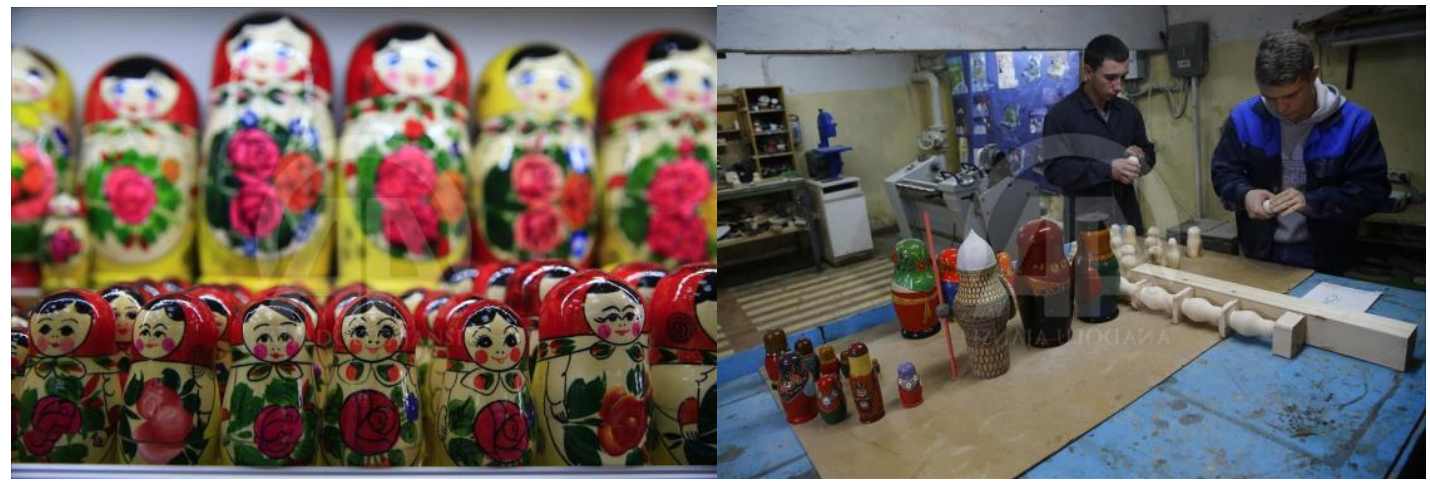

Şekil 1. Matruşkalar ve üretimi (Karacan, 2019).

Eski Yunan'da çocuklar, iple çekildiğinde kuyruksallayan ya da ağzını açıp kapayabilen tahtadan hayvanlarla oynadıkları ve kolları bacakları hareket edebilen, boyanmış kilden bebeklerin de varlığı yapılan kazılarda ortaya çıkmıştır. Eski Mısırlı çocukların yassı tahtalardan bebeklerinin başını saç yerine boncuk dizilerinin süslediği bildirilmiştir (Omatça, 2006).

19. yy.a kadar elle ya da kalıplara dökülerek yapılan oyuncaklar bu tarihten sonra makinelerle yapılmaya başlanmıştır. Gündelik yaşamdan etkilenerek yapılan oyuncaklar 20 . 
yy.da büyük bir çeşitlilik göstermeye başlamıştır (Omatça, 2006). Şekil 2'de görüldüğü gibi oyuncaklar çeşitli gruplara ayrılmaktadır.

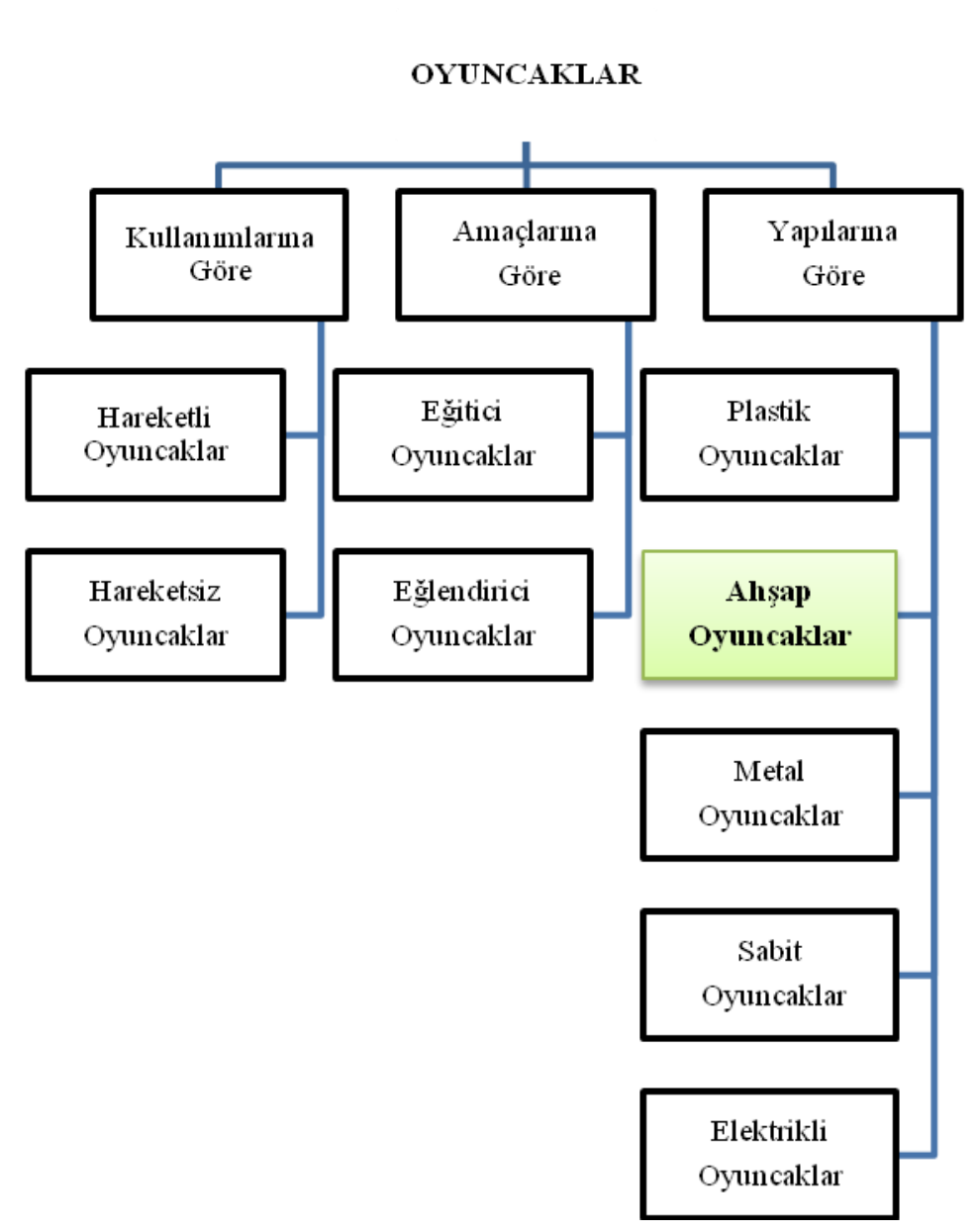

Şekil 2. Oyuncakların sınıflandırılması (Omatça, 2006).

\section{Ahşabın Oyuncak Yapımında Tercih Sebepleri}

Oyuncak, her açıdan çocuğa uygun özellikler taşımalıdır. Ancak ucuz ve işlenmesi daha kolay hammaddelere ilginin artmasıyla birlikte, oyuncak yapımında plastik malzeme kullanımı oyuncak üretiminde kullanılan diğer malzemelerin önüne geçmiştir. Daha ucuz olması, kalıp destekli imalata uygun olması nedeniyle üretim kolaylığı sağlaması, gelişmiş ve seri üretime uygun makine kullanımına olanak sağlaması, bazı türlerinin geri dönüşümlü olması ve özelliklerinin istenen yönde kolaylıkla değiştirilebilmesi plastiği oyuncak yapımında en çok kullanılan malzeme durumuna getirmiştir (Elibol ve ark., 2006).

Son yıllarda yaşanan sosyal, çevresel ve ekonomik değişimler insanların plastik oyuncakların zararlarının daha belirgin bir şekilde tespit edilmesi ile birlikte aileler oyuncak tercihlerinde özellikle ahşap malzemelerden üretilen oyuncaklara yönelmişlerdir (Dalğar ve Kaya, 2017).

Ahşabın doğal ve yenilenebilir bir materyal olması üretiminde ve satın alınmasında tercih edilmesini sağlamaktadır. Bakteri üretmesi güçtür ve bu nedenle dezenfeksiyon edilmesine gerek bulunmamaktadır. Doğal olarak kullanıldığında sağlığa zararlı bir materyal içermemektedir. Ahşaba dokunmak, onunla oynamak pozitif etki oluşmasına yol açmaktadır. Bunlara ilave olarak ahşap oyuncakların tercih edilmesinin nedenleri aşağıdaki şekilde sıralanmıştır. 
- Çevre dostudur, doğal malzemeden üretilmiştir. Üretiminde, kullanımında ve kullanım ömrü bittiğinde çevreye zararsızdır.

- Ahşap ürünleri imha etmek için özel tesislere gerek yoktur. Ahşap oyuncakta doğaya geri dönüşüm mümkündür.

- Ahşap ürünler, farklı renkleri, dokuları, kokuları ile insanlara hep sıcak, sevimli ve doğal gelmiştir.

- Desen çeşitliliği ve tasarımlarındaki uyum ile hayal zenginliği kazandırır.

- Hediyelik süs eşyaları, oymacılık ve marketri üretiminde göze çarptığı gibi renk farklılıkları ile resim ve eşyalarda farklı oluşumlar yakalamak mümkündür.

- Ahşap ürünler farklı kokuları ile özellikle gelişme çağındaki çocuklarda koku alma duyularının gelişmesinde rol oynamaktadır.

- Farklı ağırlık ve yüzey çeşitliliği ile dokunma duyusunu geliştirerek, çocukların öğrenme becerilerini gelişiminde yardımcı olur.

- Kırılan ahşap oyuncakların tamiri mümkündür. Onarımında kullanılan beyaz tutkalın yanı sıra başka tutkallar da kullanılmaktadır (D2-D3). Kırılan bir oyuncağın tamiri, çocuk ile anne-baba arasındaki iletişime yardımcı olduğu gibi gelişmesine de yardımcı olur.

- Ahşaba dokunmak, onunla oynamak çocuktaki vücut elektriğini alır.

- Ahşap oyuncaklar nesilden nesile geçen ürünlerdir.

- Tamamen geri dönüşümlüdür. Marangoz artıklarından, kereste, odun artıklarından da ahşap oyuncak yapmak mümkündür.

- Ahşap oyuncak görünümlerinin güzel olması ve sanat eserini andırması sebebi ile vitrinlerde ve oturma alanlarında sergilenebilmektedir.

- Dayanıklıdır, bozulmaz, kırıldığında yapıştırmanız, rengini değiştirmeniz mümkündür.

- Ahşap oyuncaklar sadece oyuncak ve eğitim aracı olarak değil aynı zamanda terapi amaciyla da kullanılabilir.

- Ahşap oyun araçları nesiller, kültürler arasındaki kaynaşmayı da sağlar.

- Ahşap oyuncak üretilmesi için mutlaka ileri üretim araçları ve sistemlerinin kullanılması gerekmez. El yapımı, yontma ve oyma ürünler özellikle değerlidir.

- Çocuklara üst yüzey işlemi uygulanmamış ahşap oyuncaklar alınabilir. Beraberinde alacağınız "akrilik boya" su bazlı olduğu için çocuğun kendi boyayabileceği, kendi katkısının olduğu ürün elde edilebilir.

- Ahşap ürünlerin her çeşidini herhangi bir alet kullanarak biçimini değiştirmek ve yeni ürünler elde etmek, her zaman mümkündür (hobi ve maket oyuncaklar). Hayal gücünün gelişmesinde rol oynamaktadır (Tuncer, 2012).

\section{Ahşap Oyuncak Yapımında Kullanılan Ağaç Türleri}

Ahşap oyuncakları diğer malzemelerden ayıran en önemli özelliği, doğal, sağlıklı, estetik, sağlam olmasıdır. Bunlardan sadece sağlık kelimesinin geçmesi, ahşap oyuncakların tercih sebebi yapmaya yeterlidir (Omatça, 2006).

Oyuncak üretiminde birinci derecede kayın ağacı olmak üzere bunun yanı sıra ladin, köknar, meşe gibi diğer ağaçlar da kullanılmaktadır (Demiral, 1996). Oyuncak yapımında kullanılan başlıca ağaç türleri hakkında kısa bilgiler aşağıda verilmiştir.

\subsection{Kayın}

Türkiye'de kayının doğal olarak yetişen türü Fagus orientalis (Doğu kayını) en geniş yayılış alanı Karadeniz ormanlarında görülür. Odunu kırmızımsı beyaz renktedir. Odunu sert ve ağır $\left(D_{12}=0.72 \mathrm{~g} / \mathrm{cm}^{3}\right)$, şok direnci yüksektir. Buharlandığında kolayca bükülebilir. Kurutmada dikkat isteyen bir ağaç türüdür. Fazla çalışır, kolay yarılır, işlenmesi kolaydır. Diğer ağaç türlerine göre daha geniş kullanım alanına sahiptir. Özellikle masif ve bükme 
mobilya, lambri, spor aletleri, oyuncak, alet sapları, müzik aletler, parke, tornacılık vb. kullanılmaktadır (Bozkurt ve Erdin, 1997).

\subsection{Gürgen}

Türkiye'de iki doğal türü (Carpinus betulus (adi gürgen) ve $C$. orientalis (doğu gürgeni)) yetişmektedir. Koyu renkli öz odunu yoktur. Odunu diri odun karakterinde olup, gri beyaz ve sarımsı beyaz renktedir. Odunu ağır $\left(D_{12}=0.83 \mathrm{~g} / \mathrm{cm}^{3}\right)$, çok sert, yüksek elastikiyet modüllü ve eğilme direnci ile son derece yüksek şok direncine sahiptir. Çalışması fazladır. Makine kısımları, spor aletleri, alet sapları, tarım aletleri yapımında ve tornacilıkta kullanılır (Bozkurt ve Erdin, 1997).

\subsection{Kavak}

Türkiye'de doğal olarak birçok kavak türü yetişmekte, ayrıca birçok kavak tür ve klonları suni olarak geniş çapta yetiştirilmektedir. Kavaklar ışık ağaçlarıdır. Hızlı büyürler; akarsu kenarlarında ve dolma arazide iyi gelişirler. Durgun sulu yerlerde, ağır topraklarda iyi gelişme göstermezler (Sofuoğlu, 2008). Kavakların ince tekstürde, düzgün lifli, ipek gibi parlak, dekoratif olmayan, yumuşak ve hafif $\left(\mathrm{D}_{12}=0.44 \mathrm{~g} / \mathrm{cm}^{3}\right)$ odunları vardır. Aletlerle kolay işlenir. Direnç değerleri ve elastikiyet modülü düşük olup, şok şeklinde gelen ani yüklemelere karşı orta derecede dayanıklıdır. Çalışması fazladır. Mobilyaların iç kısımlarında ve çekmecelerde, oyuncak, kutu ve sandık imalinde, dekoratif olmayan tornacılık işlerinde, kurşun kalem, lif ve kağıt endüstrisinde kullanılmaktadır (Bozkurt ve Erdin, 1997).

\section{4 Çam}

Türkiye'de doğal olarak beş çam türü (Pinus sylvestris (sarı çam), P. Nigra va. pallasiana (Toros kara çamı), P. brutia (kızılçam), P. pinea (fıstık çamı), P. halepensis (Halep çamı)) yetişmektedir. Reçine kanalları fazladır. Genellikle orta derecede yumuşak, orta ağırlıkta $\left(D_{12}=0.52 \mathrm{~g} / \mathrm{cm}^{3}\right)$, orta derecede şok direncine, yüksek derecede elastikiyet modüllü, ve eğilme direncine sahip, kolay işlenen ve iyi çivi tutan bir malzemedir. Çalışması orta derecededir. İnşaat kerestesi, doğrama, maden, tel direği, gemi güverte döşemelerinde vb. kullanılmaktadır. (Bozkurt ve Erdin, 1997). İyi bir işlenme özelliğine sahiptir. Orta derece veya kolay kurutma özelliği gösterir (Doğu ve ark., 2001).

\subsection{Sedir}

Cedrus libani (Toros sediri); diri odunu geniş, hafif kırmızımsı ile sarımsı beyaz renkte, öz odunu açık sarımsı ile kırmızımsı kahverengindedir (Bozkurt ve Erdin, 2000). Odunu sert ve orta ağırlıkta $\left(D_{12}=0.52 \mathrm{~g} / \mathrm{cm}^{3}\right)$ olup hoş aromatik kokuludur. Kolay işlenir ve yarılır. Lifleri düzgündür. Renk verme ve cilalanması güçtür. İyi yapıştırılır. Çalışması az, direnç özellikleri orta derecededir. Bina iç ve dış kısımlarında, cephe kaplaması, mobilya, kurşun kalem vb. kullanılmaktadır (Bozkurt ve Erdin, 1997)

\subsection{Göknar}

Türkiye'de doğal olarak yetişen dört türü bulunmaktadır. Koyu renkli öz odun ve reçine kanalları bulunmamaktadır. Olgun odun özellikleri taşırlar. Odunlarının rengi sarımsı beyaz ile gri beyazdır. Hafif $\left(\mathrm{D}_{12}=0.43 \mathrm{~g} / \mathrm{cm}^{3}\right)$, yumuşak olan odunları kolay yarılabilir. Lifleri düzgün ve yeknesak tekstürdedir. Direnç değerleri düşüktür. İşlenmesi ve yapıştırılması kolay, boyanması ve çivi tutma özelliği iyi değildir. İyi ve çabuk kurutulur. Rutubetli şartlarda dayanıksızdır. Bina inşaatı iç kısımlarında, mobilyada ara ve iç bölmelerde, müzik aletleri, ambalaj sandığı yapımında kullanılmaktadır (Bozkurt ve Erdin, 1997).

Şekil 3' de ahşap malzeme kullanılarak üretilmiş oyuncaklara örnekler verilmektedir. 

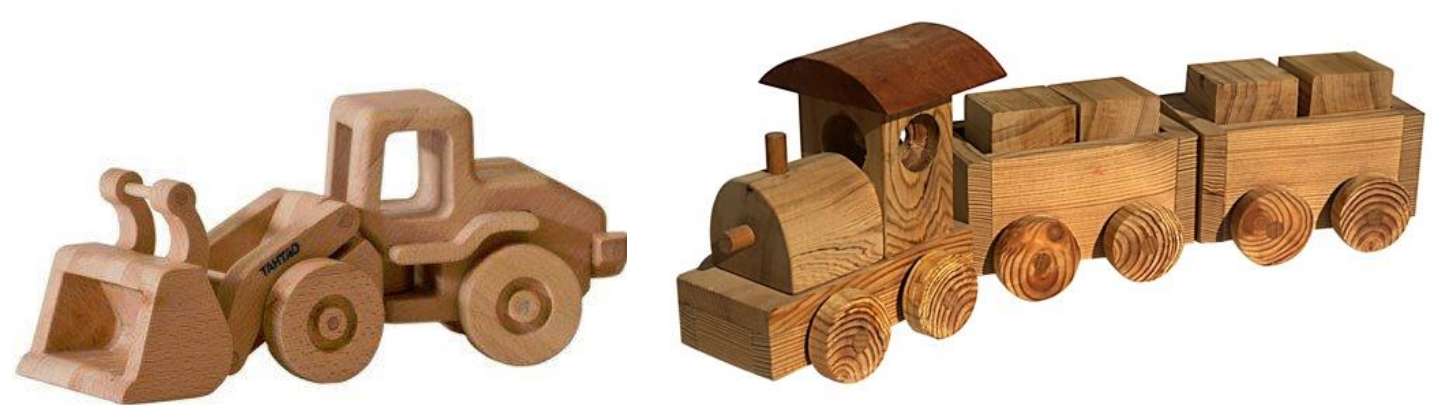

Şekil 3. Ahşaptan üretilmiş oyuncaklar (Karaarslan, 2015).

\section{Ahşap Oyuncak Ürünlerde Kullanılabilecek Kalite Sembolleri}

Ahşap oyuncak seçiminde sıklıkla karşımıza çıkan ve tercih etmemizde etken olabilecek olan kalite ve standartlarla ilgili bazı belge ve işaretler şu şeklide siralanabilmektedir (Sofuoğlu, 2009).

TSE Markası: Bir ürünün üzerinde ve ambalajında TSE markası varsa, o ürünün ilgili Türk Standartlarına uygun olarak üretilmiş ve piyasaya sunulmuş olduğunu ifade etmektedir.

TSEK Markası: TSEK markası henüz Türk standardı hazırlanmamış ürünlerin üzerinde ve ambalajında bulunur. Bu ürünün uluslararası ve diğer ülkelerin standartlarına ya da Türk Standartları Enstitüsü tarafindan kabul edilen teknik özelliklere uygun olarak üretilip piyasaya sunulduğunu belirtmektedir.

TS İşareti: TS işareti ve yanında yer alan (Örneğin TS 4600), o ürünün TSE tarafından belgelendirildiği anlamına gelmemektedir. Üretici firmanın ürününün Türk standardına uygun olarak ürettiğine ilişkin beyanıdır. TSE tarafından herhangi bir garanti söz konusu değildir.

ISO 9000: Kalite konusunda ülkemizde ulusal ve uluslararası kuruluşlar faaliyet göstermektedir. Bunlar tarafından başta ISO 9000 ve Toplam Kalite Yönetimi olmak üzere kalite ile ilgili konularda eğitim, danışmanlık ve ISO 9000 Kalite Sistem Belgelendirme Hizmetleri verilmektedir. ISO 90001987 yılında Uluslararası Standart Kuruluşunca (ISO), uluslararası standart olarak onaylayıp yayınlanan ve halen Avrupa Topluluğu ülkelerinde uygulanmakta olan bir uluslararası kalite standartları serisidir (Kurtoğlu ve ark., 1997).

ISO 9001: $\mathrm{Bu}$ seri numaralı standart, kuruluş tarafindan, tasarım, geliştirme, üretim, tesisat ve hizmet gibi değişik kademelerde belirlenen isteklerin yerine getirildiği konusunda güvence vermek amaciyla kullanılmaktadır.

ISO 9002: Kuruluş tarafindan son kontrol ve deneylerde belirlenen isteklerin yerine getirildiği konusunda güvence vermek amacıyla kullanılmaktadır.

CE işareti: CE işareti; Avrupa birliği ülkelerinde malların serbest dolaşımının gerçekleştirilmesi amacıyla yeni yaklaşım direktifleri ve küresel yaklaşım politikaları çerçevesinde 1989 yılından itibaren ürünlerde yer almaya başlayan resmi bir işarettir ve bütün AB ülkelerinde geçerli bulunmaktadır. CE işareti Fransızca "Avrupa'ya Uygunluk" anlamına gelen "Conformité Européene" kelimelerinin baş harflerinden oluşmaktadır (Sofuoğlu, 2009). $\mathrm{Bu}$ işaret, direktif kapsamındaki mamullerin; kişilerin, hayvanların, malların güvenliğini tehlikeye sokmadığının, çevreye zarar vermediğinin ve tüketiciyi koruduğunun üretici tarafindan beyan edildiğini belirtmektedir. CE işareti kesinlikle bir kalite markası olmayıp, TSE veya TSEK markası yerine kullanılmamalıdır (Kurtoğlu ve ark., 1997).

Şekil 4'de ahşap oyuncakların üzerinde görülebilecek kalite ve diğer semboller verilmektedir. 


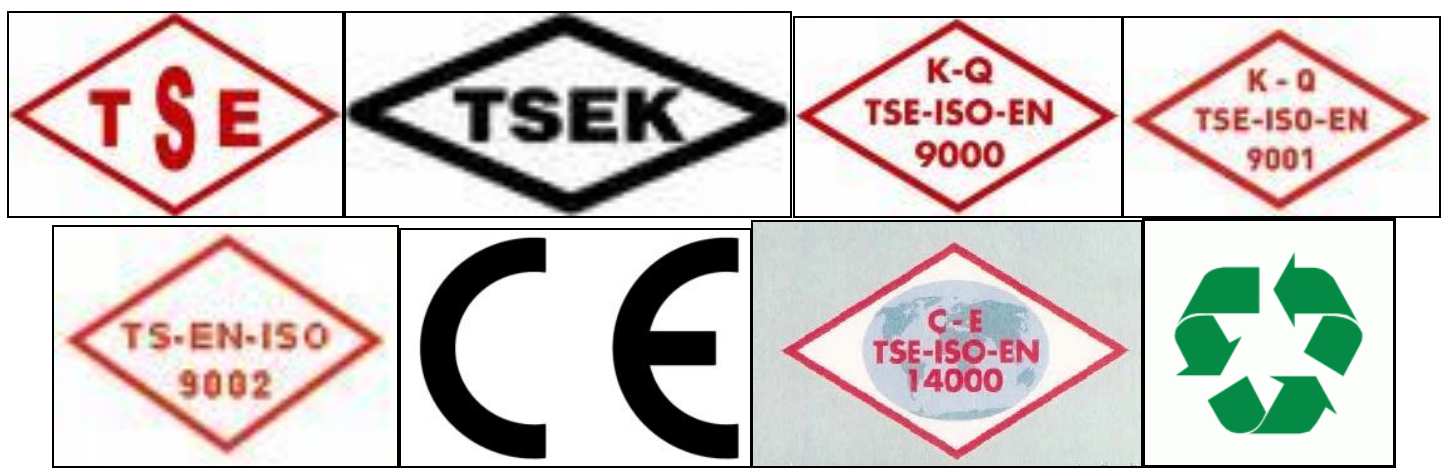

Şekil 4: Oyuncakların üzerinde görülebilecek kalite ve diğer semboller

ISO 14000: ISO 14000 serisi işletmeler tarafindan gönüllü olarak uygulanan ve bir dizi alt referans standardına (ISO 14xxx) sahip olan standartlar sistemidir. Çevrenin korunması ve sürdürülebilir üretim ana temaları üzerine inşa edilmiş ISO 14000 serisi çevre yönetim sistemleri, çevre koruyucu paketleme, ürün yaşam eğrisi değerlendirmesi, çevre denetimi, çevresel performans değerlendirmesi ve üretim standartlarında çevresel unsurlar şeklinde altı alt başlıkta on beş adet standardı barındıracak şekilde düzenlenmiştir (Kurtoğlu ve ark., 1997).

ISO 14001'in şartlarına uygunluk ve bunun bir belge ile kanıtlanması, küreselleşen dünya ticaretinde yaşayabilmenin gün geçtikçe bir ön şartı olmaktadır. Birçok sanayi kuruluşu için ISO 14001'e uygunluk belgesine sahip olmak, ürettiği malları özellikle yurtdısına satabilmek için bir zorunluluk olmaya başlamıştır (Kurtoğlu ve ark., 1997).

Geri dönüşüm işareti: Artık kullanılmayan ürünlerin, çöplerin alınıp işlenmesi ve ham madde olarak sürece tekrar kazandırılmasını ifade etmektedir.

\section{Ahşap Oyuncak Üretiminde Dikkat Edilecek Hususlar}

Tüketicilerin oyuncak satın alırken: oyuncağın fiyatına dikkat ettiğini, bilgi etiketini okuduğunu, çocuğunun sağlığına zararlı olabilecek oyuncakları tercih etmediğini ve tehlike unsuru taşıyan oyuncakları tercih etmediği tespit edilmiş bunun yanı sıra tüketicilerin, oyuncakların markasına ve menşeine bakıp bakmama konusunda yaklaşık olarak yarısının satın aldığı oyuncağın markasına ve menşeine baktığını, geri kalan tüketicilerin ise yarısının kararsız olduğunu diğer yarısının ise satın aldığı oyuncağın markasına ve menşeine bakmadan aldığı saptanmıştır (Çiçek, 2011).

Türkiye`de satılan oyuncakların yüzde 95`i hatta kimilerine göre daha da fazlasının üretimi Çin'de yapılmaktadır. Aralarında kaliteli belgeli ve kontrol belgeli ürünler olduğu kadar çocuklarda geri dönüşü olmayan hastalıklar bırakacak türden zararlı maddelerden yapılanları da olduğu görülmüştür (Çiçek, 2011).

Masif ahşap oyuncak imal eden üreticilerin, oyuncak tasarımda, kullanılacak ahşap malzemenin seçiminde, üst yüzey işlem uygulamalarında göz önüne almaları gereken hususların önemlileri şu şekilde sıralanmıştır (Elibol ve ark., 2006):

- "Kullanılacak ahşap malzeme düzgün desenli ve budaksız olmalıdır. Bu oyuncağın formunun korunması açısından önemlidir. Lif kıvrıklığı ve budaklar ahşabın homojen olmayan daralma ve genişlemesi anında şekil değiştirmelere neden olan gerilmeleri ortaya çıkaran unsurların en önemlilerindendir.

- En kesitinde yıllık halka aralıklarının eşit olmasına dikkat edilmelidir. Yıllık halka aralıklarının eşitliği doku homojenliğinin bir göstergesi olup, şekil değiştirmeyi ve şekil değiştirme kaynaklı çatlamaların ortaya çıkmasını engeller. 
- Çocuk sağlığı ve oyuncak kullanımı açısından reçine keseli veya yoğun reçineli yüzeylere sahip ahşabın kullanılmaması gerekir. Sıcak ortamlarda reçinenin akıcılığı artarak oyuncakla oynayan çocuğun eline bulaşır ve oyuncağın kullanımını zorlaştırır.

- Kullanıldıkça kolay aşınan ve kıymıklanan bir yapıda, yeterli sertlikte olmalıdır.

- Zaman zaman oyuncağı ağzına götürerek oynama ihtimali yüksek üç yaş altı çocuk oyuncaklarında maun, meşe, kestane gibi ekstraktif madde (ağaç malzeme içerisinde bulunan, malzemenin yapışma, boya-vernik tutma gibi özelliklerini olumsuz yönde etkileyen, tanen, sepi maddesi gibi bileşikler) miktarı fazla olan ağaç türleri tercih edilmemeli, bu yaş grubu çocuk oyuncakları genelde boyanmamalıdır. Üç yaş üstü çocuk oyuncaklarında ise su bazlı boya ve vernikler, doğal boyalar kullanılmalıdır.

- Diğer tüm malzemelerden yapılan oyuncaklarla birlikte ahşap oyuncaklarda keskin kenarlı hatlar kesinlikle bulunmamalı, oyuncak yuvarlak hatlardan oluşturulmalıdır. Böylelikle, çarpma kaynaklı olası kazalar önlenmiş olur” (Elibol ve ark., 2006).

- İç mekanda kullanılacak olan ahşap oyuncaklar için, rutubet değerinin \% 8 olması yeterlidir.

- Ahşap oyuncak tasarımında, çocukların yaş gruplarına göre, antropometrik ölçüleri dikkate alınarak, ergonomik boyutlara uygun tasarımlar yapılmalıdır

- Ahşap oyuncak tasarımında, oyuncak sadece bilişsel alanda değil, tüm gelişim alanları için bir öğrenme aracı olarak değerlendirilmeli ve olabildiğince çok boyutlu tasarıma önem verilmelidir,

- Bu açıklamalar uyarınca, ahşap malzemeden üretilen oyuncaklarda solvent ile ağartıcı ve zehirli kimyasallar kullanılmadan, doğal ve sağlı̆ga zararsız üst yüzey maddeleri kullanılmalı, yüzeydeki pürüzler, zımpara işlemi ile giderilerek, yüzey düzgünlüğü ve kenar düzgünlüğü sağlanmalıdır (Mercan, 2018).

- Tasarlanan ahşap oyuncak; çocuk onu yere attığında, ağzına götürdüğünde veya elinde oynarken istem dişı bir davranışla uygulayabileceği kuvvete istinaden küçük parçalara bölünmeyecek bütünlükte ve dayanımda olmalıdır. Parçalanması halinde oyuncakların ufak parçaları çocuklara fiziksel olarak zarar verebileceği gibi yutma ve boğulma tehlikesi oluşturabileceği dikkate alınmalıdır.

Ahşap oyuncakların üretiminde çocuk sağlı̆̆ı ve can güvenliği açısından uyulması gereken bazı kriterler bulunmaktadır. Bu konuda, dünya çapında ISO 8124-6:2014, 2009/48/EC, EN 71, GB 6675-2014, ASTM F963-17gibi çeşitli standartlar ve yönetmelikler mevcuttur. Türkiye'de ise, bu kriterler TS EN 71 standardı ile düzenlenmiştir. Buna göre, 04/10/2016 tarihli, 29847 sayılı Resmi Gazetede yayınlanan Gümrük ve Ticaret Bakanlığı'nın “Oyuncak Güvenliği Yönetmeliğii” kapsamında üretilen oyuncaklar, TS EN 71 standardında belirtilen hususlar çerçevesinde test edilerek güvenli olduklarına dair belgelendirilirler (Mercan, 2018).

Üretilen oyuncakların CE İşareti taşıması uygun olduğunda, Oyuncak Güvenliği Yönergesi'nde TS EN 71 (Oyuncak Güvenliği) belirtilen temel güvenlik gereksinimlerini karşılaması gerekmektedir. Üreticilerin bu konudaki diğer sorumlulukları maddeler halinde şu şekilde belirtilmiştir (Anonim, 2019).

- “Oyuncağın öngörülebilir ve normal kullanım süresi boyunca temel güvenlik gereksinimlerine uyacak şekilde tasarlandığından ve üretildiğinden emin olunmalı,

- Üretilen oyuncaklar için güvenlik testleri yaptırılmalı,

- Teknik dosya ve belge hazırlanmalı ve bunların 10 yıl süreyle saklanmalı,

- Oyuncak üzeri ya da ambalaj üzerinde teknik bilgilere yer verilmeli,

- Oyuncaklar için yapılan şikayetler araştırılmalı ve gerekli tedbirler alınmalı, 
- Uyumlu olmayan oyuncakların uyumlu hale getirilip kayıt tutulmalı,

- Tedarik zinciri ve diğer ekonomik ortaklardan CE belgesi talebi,

- Aynı oyuncakların üretimde uygunluk sürekliliği sağlanması, gerekmektedir.”

\section{Sonuçlar ve Öneriler}

Bu çalışmada, masif ağaç malzemenin oyuncak yapımında kullanımı konusunda yapılan bazı önceki çalışmalar incelenmiş ve önemli bilgilere ulaşılmıştır. Elde edilen bilgiler doğrultusunda şu sonuçlar söylenebilir;

- Masif ağaç malzemeden üretilen oyuncuklar, üretim esnasında odun kusurlarının arındırılması gibi önemli kurallara uyulduğu takdirde, diğer malzemelerden üretilen oyuncaklara göre daha sağlıklı olmaktadır.

- Üreticiler ahşap oyuncak üretiminde gerek tasarım, gerek kullanılacak ağaç türünün seçimi, ve gerekse koruyucu ve renklendirici üst yüzey işlemlerinin seçiminde, insan ve çevre sağlığını en önemli parametre olarak görerek seçimlerini gerçekleştirmelidirler.

- Çocuklar bu konuda yeterli bilince sahip olmadıklarından dolayı oyuncak seçiminde üreticiler ve ebeveynler hassas davranmalıdırlar.

\section{Kaynaklar}

Anonim. (2019), Oyuncaklar için CE belgesi. Retrieved December 22, 2019, from https://www.belgedanismanlik.com/oyuncaklar-icin-ce-belgesi

Bozkurt, A. Y., Erdin, N. (1997), Ağaç teknolojisi, İstanbul: İstanbul Üniversitesi Orman Fakültesi Yayınları.

Bozkurt, A. Y., Erdin, N. (2000), Odun anatomisi, İstanbul Üniversitesi Yayın No: 4263, Orman Fakültesi Yayın No: 466.

Çiçek, M. (2011), Tüketicilerin oyuncak satın alma davranışları ve ülke orjini etkisi üzerine bir araştırma, Aksaray Üniversitesi Sosyal Bilimleri Enstitüsü, İşletme Anabilim Dalı Yüksek Lisans Tezi.

Dalğar, T., Kaya, A. İ. (2017), Oyuncak tercihinde ahşap malzeme özelliklerinin incelenmesi, İleri Teknoloji Bilimleri Dergisi, 6(3), 9-16.

Demiral, Ö. (1996), Eğitici Oyuncak Yapımı. İstanbul: Esin yayınevi.

Doğu, D., Koç, K. H., As, N., Atik, C., Aksu, B., Erdinler, E. S. (2001), Türkiye'de yetisen endüstriyel öneme sahip ağaçların temel kimlik bilgileri ve kullanıma yönelik genel değerlendirme, İstanbul Üniversitesi Orman Fakültesi Dergisi B Serisi, 51(2).

Elibol, G. C., Kılıç, Y., Burdurlu, E. (2006), Okul öncesi çocuk oyuncaklarında malzeme kullanımı ve 4-6 yaş çocuklarının renk tercihleri, Sosyal Politika Çalışmaları Dergisi, 9(9), 35-44.

Karaarslan, M. (2015), Çocuk ve doğa: sağlıklı ahşap oyuncak, Retrieved December 22, 2019, from https://indigodergisi.com/ website: https://indigodergisi.com/2015/04/cocuk-vedoga-ahsap-oyuncak/

Karacan, S. (2019), Rusya'nın simgesi matruşka bebekler, Retrieved December 22, 2019, from Anadolu Ajans1 website: https://www.aa.com.tr/tr/pg/foto-galeri/rusyanin-simgesimatruska-bebekler

Kurtoğlu, A., Koç, K.H, Erdinler, E.S., (1997), Mobilya - kullanıcı ilişkileri ile mobilya seçiminde dikkat edilecek hususlar, İstanbul Üniversitesi Orman Fakültesi Dergisi, Seri 
B, Cilt 47, Say1:1,2,3,4.

Mercan, C. (2018), Ahşap oyuncakların çocuk gelişiminde yeri ve ahşap oyuncaklar için tasarım önerileri, Hacettepe Üniversitesi Fen Bilimleri Enstitüsü A ğaçişleri Endüstri Mühendisliği Anabilim Dalı.

Omatça, İ. (2006), Ahşabın, oyuncak üretiminde kullanımı ve önemi. Dumlupınar Üniversitesi, Simav Teknik Ĕ̆itim Fakültesi, Mobilya ve Dekorasyon Ĕgitimi Bölümü, Lisans tezi.

PAGEV. (2017), Türkiye oyuncak sektör izleme raporu 2017, Retrieved from https://www.pagev.org/upload/files/Hammadde Yeni Tebliğ Bilg. 3/Oyuncak Sektör Raporu 2017.pdf

Sofuoğlu, S. D. (2009), Çocuk ve mobilya, Bartın Orman Fakültesi Dergisi I.Ulusal Batı Karadeniz Ormancılık Kongresi Bildiriler Kitabı, Özel sayl(Cilt 1), 101-107.

Sofuoğlu, S. D. (2008), Bazı yerli ağaç türü odunlarının işlenme özelliklerinin yüzey kalitesi üzerine etkileri. İstanbul Üniversitesi, Fen Bilimleri Enstitüsü, Orman Endüstrisi Makinalarl ve İsletme Anabilim Dall, Doktora tezi.

Tuncer, Y. (2012), Ahşap oyuncaklar. Dumlupınar Üniversitesi, Simav Teknik Ĕgitim Fakültesi, Mobilya ve Dekorasyon Eğitimi Bölümü Lisans tezi. 